\title{
Application and integration of principles and uses of international trade in regulatory systems
}

\author{
Aplicación e integración de principios y usos del comercio internacional de sistemas \\ reglamentarios \\ Dimitris Liakopoulos 1 ORCID
}

Fecha correspondencia:

Recibido: 9 de septiembre de 2019. Revisión: 29 de noviembre de 2019. Aceptado: 13 de febrero de 2020.

Forma de citar:

Liakopoulos, Dimitris. "Application and integration of principles and uses of international trade in regulatory systems". Revista CES Derecho. Vol. 11, No. 1, enero a junio de 2020, 55-88.

Open access

Términos de uso

Licencia creative commons

Ética de publicaciones

Revisión por pares

Gestión por Open Journal System DOl: http://dx.doi.org/10.21615/ cesder.11.1.3

ISSN: 2145-7719

Sobre los autores:

1. Full Professor of European Union Law at the Fletcher School-Tufts University (MA in international law and MA of Arts in Law and diplomacy). Full Professor of International and European Criminal and Procedural Law at the De Haagse Hogenschool-The Hague. Attorney at Law a New York and Bruxelles. The present work is updated until September 2019.

\section{Abstract}

The present work is concentrated on thoughts and perspectives of unwritten soft law codification models in international trade system, following an especially comparative and critical analysis with the hard law systems and regulatory integration in private, European and international economic law.

Keywords: CISG, art. 7 CISG, coding models, rule of law, EU, international private law, international economic law, codification, soft law, hard law.

\section{Resumen}

El presente trabajo se concentra en los pensamientos y perspectivas de los modelos de codificación de leyes no escritas no escritas en el sistema de comercio internacional, siguiendo un análisis especialmente comparativo y crítico con los sistemas de leyes duras y la integración regulatoria en el derecho económico privado, europeo e internacional.

Palabras clave: CISG, art. 7 CISG, modelos de codificación, estado de derecho, UE, derecho privado internacional, derecho económico internacional, codificación, derecho blando, derecho duro.

\section{Introduction}

\section{The role of hard and soft law tools in ensuring the uniformity of international} trade relations

The formation and processing of law relating to international business relationships constitutes the most significant material area to allow the understanding and assessment of the adequacy of soft law instruments to affect the practice in order to achieve an effectively uniform discipline of situations that do not even exist and are exhausted within a single legal system.

International trade law, even though is elaborated in offices and bodies particularly involved with trade and at the protection of specific interests, is characterized by a discipline elaborated according to characteristics that go beyond a specific local area. It is a matter of legislation which, contrary to what occurs in other sectors of economic law, is characterized by 
formulations adopted by virtue of expressive techniques suitable to be applied in various places in which it is necessary to carry out their complete implementation and guarantee their effectiveness even if they are not attributable to the normative models typical of traditional forms of hard law that do not resort to the use of "types" or institutes explicitly belonging to certain systems (Horn, Schmithoff (eds.), 1982; Dalhuisen, 2016).

The relative discipline is often governed by rules suitable for an ultra-local application other than real hard law rules adopted directly or indirectly recognized by bodies in charge of regulatory power within the various local sovereignties where disputes must be settled and/or performed various reports related to international trade. In this perspective, the importance of codified discipline in mercantile relationships is emphasized through the use of soft law normative tools often formed through the direct participation of classes interested in these relationships by virtue of a spontaneous reconciliation of various needs and interests of various subjects as well as state systems in which their trades are to gravitate (Fletcher, Mistelis, Cremona (eds.), 2001; Berger, 2001).

International trade law is the most qualified venue in which those forms of soft law have emerged allowing the elaboration and normative training related to these relationships. Mercatores training is gradually consolidated in various soft law legal expressions and tools that have actual characteristics in real codification rules belonging to hard law and in judgments thanks to the use of techniques and solutions accepted and implemented within the various territorial areas subject to the various state sovereignties in which international trade must be carried out.

This circumstance explains the reasons for which even in the centuries when exasperated tendencies turned towards a national differentiation of commercial law on the occasion of its transformation from customary into legal law of the state type there was no discontinuity between regulations in force in the various national legal systems although present in other sectors of international economic relations. It is true that sometimes in certain historical moments of particular success of state codification movement of commercial law the factors of national law diversification have hindered the complete international uniformity of the relative discipline. But it is equally true that in no other field of law exists such a dense series of relationships whose normative solutions introduced in the various state codifications even in the greatest expansion of law nationalism are substantially convergent with reference to the derogable discipline from the interested parties to the relative relationships. And this result is due to the wide employment and importance that have assumed in this regard the normative tools of hard and soft law of international origin, the contained contents have emerged from time to time according to various ways through which they have been reconstructed and rationalized the results emerged in practice or the needs highlighted in this context.

\section{The progressive involvement of states in the elaboration of international normative instruments related to international trade}

The transnational uniformity of international trade law has been greatly favored and achieved during the last century, by the activity of specialized organisms that have sought through different techniques to codify the most appropriate discipline or at least the most relevant principles, the relationships that gravitate around this phenomenon not only through real agreements of uniform law but also by virtue of 
Guidelines, the elaboration of principles, contractual standards, model laws or mandatory minimum standards. Such international organizations sometimes have characteristics of interstate organizations and high non-intergovernmental characters.

The unification technique was initially identified in the elaboration of privatistic tools without any kind of imperativity towards their recipients. This is what happened in International Law Association when it was given (since 1980) to prepare the York and Antwerp rules (Fletcher, Mistelis, Cremona (eds.), 2001) related to common goods, which they represented and still represent one of the happiest examples of rationalization of rules, practice of commercial traffics and spontaneous adaptation applied by all the interested parties in contracts of international sale and charter-party as well as in the most frequently adopted international bills of lading

Regardless the location and procedures for their elaboration, we have always been concerned with ensuring the consistency of these regulations and protection of minimum standards corresponding to various needs satisfaction of different and often conflicting private interests within the various states involved in the related reports. Therefore, both non-intergovernmental and governmental organizations have increasingly become concerned about collaboration not only with the various economic associations and of ad hoc working groups, but especially with states in formulation and choice of various international regulatory instruments to be adopted from time to time in order to guarantee both the maximum possible consistency with the objectives indicated and the effects of various relevant regulations in this regard.

This method is regularly and intensively used with great profit in the elaboration and implementation of international conventions concerning the uniform law of international trade at least since the beginning of the second half of the last century when changes in international economic order have occurred as well as in the same structure of international community as a result of the emergence of developing countries wishing to assert their interests and their political weight directly in the drafting of legislation on international trade. Precisely for this reason it has been activated UNCTAD/Untitled Nations Conference on Trade and Development and other international organizations related to the United Nations system, i.e. a privileged center for the elaboration of international trade law also through an extensive use of soft law tools.

The need for elaboration of international normative instruments with adequate participation of states and representative bodies of various private subjects involved in the related reports

Principles and rules relating to international trade, hitherto developed, were not considered consistent with the protection of their interests and economic growth. Developing countries often did not feel guaranteed by them. It therefore certainly had a significant impact on the practice and choice of hard and soft law models related to the elaboration and codification of international trade law, especially in the second half of the last century.

Excessive attention to state interests, and in particular of some of them without taking into consideration and direct involvement the bodies representing the interests of different private subjects in various capacities participating in international trade causes effects such as to jeopardize the success and effects of various types of uniform law regulations developed in this way. Economic and commercial components, 
if excluded from international decision-making process, tend to turn their dissuasive action with respect to solutions adopted without adequate attention to their interests, within the decision-making processes of implementation and adaptation of such normative choice within the single states in which they are able to exercise greater political influence. Their action will be aimed at conditioning ex post the effectiveness of various regulatory instruments developed at international level trying to limit their scope if not consistent with their needs as they are not adequately represented and held in due consideration during their training.

It should be noted that the lack of involvement of subjects directly interest, since the development of various types of regulations related to international trade that affect them, makes these last vulnerable and prove to derailment (Teubner, 1997).

What is now indicated also clarifies the characteristics of the most efficient model in the elaboration and selection of specific types of uniform law to be adopted and in particular if they have a derogable content and they can be foreseen on soft law instruments that for their structural characteristics are more demanding to their normative contents by those interested in their implementation. The need for timely involvement of representatives of all economic interests in relation to which the uniform law is destined to produce its effects and in particular adequate consultation extended also to non-intergovernmental organizations where such interests are present or even indirectly represented. It is a matter of taking realistic note that although without renouncing the role and function of non-intergovernmental organizations, especially with regard to certain types of relationships, the most appropriate forum for the drafting of uniform law that affects international trade relations with macroeconomic effects cannot be in inter-state organizations and in particular in specialized UN institutions, where the state interests on a universal basis are adequately represented.

A fruitful participation and adequate involvement of various private interests in the process of drafting uniform law, even in cases of UN specialized institutes, and in particular UNCITRAL, is absolutely essential. Naturally, the extent of such participation, the determination of regulatory intervention and the choice of relative attendance to their elaboration must be qualified in order to guarantee the necessary understanding of all the actual needs that are answered in this regard. Only in this way is it possible to guarantee the processing and approval phases, as well as the choices of regulatory tool relative to the uniform discipline of international trade relations, can be carried out with full awareness of the balances accumulated in the practice on which we intervene and the reactions that the related effects may have on the success and acceptance of this legislation.

Scope and necessary presence of international conventions to ensure uniformity of discipline of certain relations related to international trade

With regard to the type of international regulatory instruments that has been used in the last century with greater intensity in order to guarantee the unification or more precisely the uniformity of international trade relations, which are sometimes relevant, is certainly represented by the instrument of international convention. Only in this way on many cases it was considered possible to effectively pursue the uniform operation of the discipline adopted, contrary to what would have happened through other instruments that allow to achieve only harmonization or uniformity with more attenuated effects of guarantees related to the implementation of the normative parameters adopted. 
In some cases, other instruments and in particular those of soft law are not able to adequately limit the potential exceptions of the private autonomy and/or various state systems that can operate in a reductive sense or even in a derogatory sense with respect to the discipline in their expected scope. In the last century they have lent themselves to a profitable use only when destined to carry out a mere recognition function of the results obtained by the practice and through it the regulatory provisions widely accepted by the relevant recipients to balance relationships between subjects who they are part (Van Houtte, 2002).

The legislation laid down in international conventions of uniform law it is capable of imposing its own discipline with mandatory scope and contents, at least for a part of them both towards the interested parties and national legal systems. This is particularly adequate to regulate international relations in which the position of subjects involved in them is for various reasons unequal and/or whose effects are destined to have a particularly significant impact on macro-economic relationships.

In this perspective, the uniform law adopted by virtue of international conventions has qualified as the most suitable to ensure an applicative space at least partly unchangeable in a reductive sense by the states and even less by private individuals. In this way international conventions of uniform law have proved to be the only normative instruments capable of imposing a balanced assertion of a certain international trade relationship between subjects lacking open economic power that must be incomprehensible and necessary when are present assumptions that justify and legitimize the application in its own bound legal framework, and independently determined by uniform law, towards its recipients.

In this regard, the presence of circumstances indicated to adapt this type of uniform legislation prevails over internal rules. This prevalence is justified according to special rules adopted inherently on uniform law conventions and to imperativity characteristics envisaged in relative legislative contents and in specific provisions endowed with such effects.

It can be concluded that by virtue of any justificatory reason previously indicated to norms of uniform law provided for in international conventions, both legal systems in which they are covered by constitutional protection and laws that cover it are not only deprived to indicate limits regarding their exceptibility by virtue of the exercise of private autonomy, but above all of a substantially identical prevalence over the rules of domestic law. To these last residues only the task of operating the completion of their discipline when it is free of completeness and exhaustiveness characters.

From this viewpoint there is a clear configuration of situations in which the use of international conventions depends on objectives and relations of uniform law

To a complete and efficient operation of uniform law elaborated and adopted under international conventions, the modalities and their entry into force, often turned out to be excessive, making the relative effects not adequate to their function, which has caused the incessant and rapid evolution of matter. If the preparatory and interlocutory phase prior to their current norm are protracted over time, the uniform law foreseen in international conventions can be considered satisfactory especially in the presence of rigidity of procedures for updating the related regulations. The elaboration base of about 5-7 years and that concerning their entry into force for a 
further 7 years (with possible further variations according to the number of ratifications and/or requests requested), follow those concerning the unavoidable updates often adopted through additional protocols to the original normative text and others through real new conventions. In both cases there is a further phase which, if not adequately simplified and suitable to provoke identical evolutionary effects towards all the recipients of the original standardization as well as causing delays, involves possible overlapping of uniform disciplines with inevitable negative effects. So much so that we can even verify real conflicts between norms of uniform law intended to operate within the same scope of application and the same state system.

\section{Scope, effects and characteristics of soft law instruments adopted internationally in international trade relations}

Even today it is difficult to imagine more effective instruments than international conventions in order to arrive at a uniform law, at least in cases where such uniformity requires the presence of mandatory rules where there are unbalanced contractual positions or recourse to allocation of risks or costs of certain events according to binding distribution criteria also with regard to state regulations that must be implemented.

In this perspective the scope and results of the efforts made at various international level in order to develop alternative instruments to international conventions need to be assessed. These are acts normally belonging to soft law that for the more limited times related to the specific processing methods and flexibility that characterizes them also in relation to the possible impact on their discipline of any interventions made by state systems and exercise of private autonomy are more likely to provide a discipline of international trade relations consistent with needs of business practice when the above-mentioned circumstances that require the use of the instrument of the international convention do not occur. Among these soft law instruments alternative to international conventions are various model laws related to aspects of international trade relations that allow greater flexibility and alternative solutions to states and to the same subjects interested in their discipline as it occurs with regard to international trade regulations (Boyle, 1999, pp. 530ss). This is a type of legislation with similar effects to those of uniform commercial code of the United States that just because it is not binding, has represented the most appropriate vehicle with respect to constitutional constraints to promote the harmonization of commercial law between the various states. With the regulatory instruments now indicated, a more or less detailed discipline concerning a specific type of relationship with reference to which state systems and judges belonging to them are under no obligation of adaptation and/or application, even if normally adapt to them.

The positive use of this model depends on conviction's intensity extent that individual national legal systems and various judges, besides the same direct beneficiaries place in this discipline adhering to it and the underlying values to be at least inspired in providing confidence and certain try of regulated relationships. This conviction has sometimes been so much felt by states and their recipients that they involve their adoption and favor the extension of its scope of application to include not only relations without international characteristics but also relationships similar to that expressly adjusted. This is what has happened with regard to the model law on international commercial arbitration (Bergsten, Kröll, 2011) whose contents have been in some cases also to civil matters and controversial issues without international characteristics. In any case, the effective uniformity achieved by this discipline depends not only on the specific reception methods used by the latter and by their final recipients, 
but also on their use by judges in the integration of relevant regulations in this regard within the framework of relative conventional regulations for carrying out the arbitration procedure determined by the parties. And it is for the profiles now indicated that the discipline of various model laws practically used in practice is rarely identical within the various legal systems and with regard to various international trade relations, even if it significantly influences their content due to the reliability of the source from which it is adopted (Gélinas, 2016).

These model laws characteristics, with respect to the objective of guaranteeing an effective uniformity of relations governed by them, are even more valid for another normative instrument adopted among the various soft uniform law techniques (Honnold and Flechtner, 1999). These are legislative guidelines aimed at indicating only possible regulatory solutions, often among them, alternatives that codify those used in the best practice of the sector, which is justified on the basis of specific economic and technical ratio laid down in their elaboration. A regulatory instrument that is largely conditioned by specific determinations of various state regulations and by restrictions related to its use by judges in resolving the various disputes concerning the methods of its use according to characteristics of the proposed solutions and the possible variations envisaged in guidelines.

The same findings are valid to the scope and regulatory effects of model contracts rules or to international trade terms drawn up by intergovernmental or international non-governmental organizations among which we highlight the importance they have had and still have in relations of international trade the Incoterms related to the meaning and scope of the most important clauses of international sales.

As confirmed by the Court of Justice of the European Union (CJEU) in case: C-87/10, Electrosteel Europe S.A. of 8 June 2011'1 the use of these rules and in particular those provided for in Incoterms appears to be more and more widely emphasized in case law. It has been clarified that even without any referral formulated by the contracting parties, an appeal can be made as representative of a customarily used in trade, suitable to clearly identify without necessity to resort the substantive law applicable to the essential profiles of contractual discipline, i.e. the place of delivery of goods relating to a sales contract. In this way Incoterms, as they are customarily used in commerce even if they are not recalled by a specific expressed or implicit will or by a negotiation practice previously adopted by the contracting parties, can be applied. And this solution is confirmed by the provisions of art. 8, par. 2 of the United Nations Convention on Contracts for the International Sale of Goods of Vienna of 1980 (CISG) (Schlechtriem, Schwenzer (eds.), 2010; Jansen, Zimermann, 2018), where it is recognized that uses in practice and codified by particularly qualified international bodies (such as Incoterms) regulatory non-state characteristics of international trade applicable even without any contractual reference to it. These rules are expected to be directly applicable without reference to the substantive law applicable to the contact at least when subtracted from international trade terms equipped with an adequately complete and self-sufficient regulation (Horn, Schmitthoff, Barrigan (eds.), 1982).

Not even the authoritativeness of these sources and indications now mentioned concerning the operations of the relative regulations guarantee the certainty of their effective application due to their non-equivalent character to the prevalence and imperativeness that qualify some uniform law regulations adopted under international conventions. Yet these rules, especially when prepared by specialized non-governmental 
organizations, represent the synthesis of solutions usually adopted by the best practice and the most efficient applicable discipline according to the rationalization of these results through work carried out by experts in the sector. These associations in compliance with the requirements relating to the best functioning in the sector and with any mandatory rules of each state system, are in most cases endowed with a very similar effectivity to what characterizes the norms of uniform law even in the presence of their reduced normative imperativity.

Value and function of axiological soft law sources in the regulation of international trade relations

The positive characteristics of various sources of soft law emerged in the field of international trade law, especially when equipped with adequate regulatory completeness and relative expressive principles of specific values with an objective character, guarantee an adequate effectiveness despite the lack of mandatory efficacy towards states and subjects that participate in the relative contractual relations. These can be qualified as sources of fair rules for the average case, usually present in the context of international trade relations. In this sense, even we tend to recognize such sources as a real ordering function so as to be considered as having a recently defined axiological value from which the interpreter cannot disregard the assessment of behavior and construction of contents related to relationships of international trade. By virtue of their character, the interpreter must consider the problem of compatibility of possible derogations, even if allowed to the elation discipline at least with respect to their consistency with the axiological values of the legislation envisaged in sources now indicated in order to evaluate their legitimacy and redefine the scope by establishing its scope in the perspective indicated by the values expressed in it.

Internal regulations are no longer a hostile environment but an environment particularly suited to receiving a timely and complete implementation of uniform law even if adopted by virtue of soft law instruments. And it is precisely in this perspective that choices regarding the concrete determination of normative contents of reports relating to international trade are consistent with solutions adopted or at least non-contradictory with values expressed in the corresponding provisions foreseen in international instruments of soft law without specific scope and effects, imperative for states and mandatory for the parties. Often their operation and employment takes place even beyond the respective scope of application with procedures and procedural rules that are complementary to the substantial discipline of soft law instruments of international origin with contents of uniform law that further favor a more complete implementation. They are suitable and not only for the purpose of better implementing the application of these regulatory sources within the specific characteristics of each national regulatory environment, but also to ensure their integration into these systems according to criteria consistent with their principles. The rules of soft law of international origin especially if supplemented by procedural rules in the sense now indicated are in any case an essential tool to maintain a constant adaptation to international parameters of various domestic law regulations as well as the content provided in the corresponding disciplines of contractual relationships sometimes relevant according to determinations made by the parties concerned.

The importance of choices adopted in various regulatory instruments in force in national laws and in solutions adopted in arbitration and in front of the national courts during which the tendency to ensure compliance with various types of sources is clearly evident; of uniform law, even if they are sources of soft law, developed in an 
international environment. In this way national regulations and jurisprudential solutions adopted by judges are increasingly modeled on international ones, ceasing to be a condition and a limit to their operation. Often they increasingly represent the guarantee and completion of effectiveness even in cases where their characteristics and/or their origin are not able to fully realize it.

From this consideration there is a need to give priority to international trade relations solutions and interpretative criteria aimed at obtaining an internationalized application to the maximum extent permitted by the corresponding normative formulation and negotiating contents applicable to them, taking into account all sources in this regard relevant to make the regulatory context coincide with the social-economic in which these relationships are destined to affect and produce the relative effects. In this way, not only the national provisions and various contracts relating to international trade should be considered, but also the broader international regulatory framework in which these relations must also include the principles and rules that can be derived from different models and sources adopted internationally to achieve uniformity of relationships that do not end within a single legal system.

And the interpretative profile now indicated offers a precise indication of the role and effects of various types of sources of uniform law understood as a whole. This results are of sure conclusion. From these we cannot disregard the evaluation and identification of various reports normative contents relating to international trade but also the application of such reports of relative national rules. It is also in this perspective that the contents and function of Guidelines of the principles of contractual standards of model laws and international trade terms drawn up at international level must be evaluated in addition to the norms of uniform legal conventions.

An aspect already indicated in the previous paragraphs is specified. The interpreter must not be limited to the application of hard law of international norms of uniform law with mandatory content for the states and which is mandatory for the parties who have the same national laws that are conducive to international trade. It must assess the extent and effects of international trade relations taking into account the environment and the more varied international regulatory context in which these relationships produce their effects, to which are referred to not only the whole of the mandatory derogable legislation of uniform law relative to the moment in which it is necessary to determine the contents and evaluate the effects but in particular also that foreseen in the various soft law instruments. With respect to these rules, a constructive dialogue of sources must be encouraged, which must be the element that characterizes the assessment of regulatory instruments relevant for the regulation of international trade relations in the new millennium.

In this sense, we intend to examine the characteristics and effects of the presence and scope of soft law principles related to international contracts on the basis of their codification by Unidroit and those dedicated to inter-creative criteria that can be used in connection with regulations of uniform law applicable to them with specific regard to what has been elaborated in the context of the almost entirely derogable content (and as such comparable to the soft law legislation) which has found its most significant expression at CISG (Schlehtriem, Schwenzer (eds.), 2010). 
Interpretative criteria of uniform law's normative arias by virtue of art. 7 of CISG

Evolution of various sources of international origin relating to furniture sales is particularly significant and suitable to offer an adequately representative model of dialogue between different regulations and above all of the criteria relating to their interpretation. Rules that are indicated besides being habitually respected or employed by the same contracting parties also taking into account uses codified by the various international organizations responsible for the development of international trade. This evolution highlights effective solutions because it is usually shared with techniques of integration and coordination of various legal sources of hard and soft law or interpretive criteria characterized by common perspective to satisfy the need for solutions of various interstate cases.

The effectiveness of use of a substantially uniform sale regulation of mobile goods, in various national legal systems, and the importance of legislation adopted by $\mathrm{CIS}$ as a reference of methodological model for the concrete determination of contents and relative choices that must be privileged in order to obtain uniform provisions in the regulation of contractual relations of international trade, is confirmed. It results not only as a central moment in the uniform discipline concerning international sales but also as a useful example of the use of techniques and methods of interpretation to use more generally on the concrete determination of the various international trade relations with specific reference to the reconciliation and mutual integration of the various regulatory sources relevant to delay.

Within the scope of this agreement, regulatory parameters have been developed to guide the interpretation by specifying (and adapting to) the particular needs of its contents, criteria generally valid, on occasion of regulations application concerning various international laws adopted in relation to article 7, CISG. The latter has played a leading role in application of regulations, which has sought to consolidate in a complete and convincing way the results of the most important jurisprudential indications concerning the interpretation and integration of norms of uniform law belonging to hard and soft law (Janssen, Meyer, 2009, pp. 145ss). As far as law norms for the codification of these criteria were concerned, precise traces had already emerged on the occasion of formulations adopted in this regard in some conventions immediately preceded to it "as for example art. 3 of Hamburg rules on the maritime transport of things of 1978". Also on the basis of these indications it was already possible to identify interpretative criteria, subsequently developed in art. 7 CISG with methods and formulations to be the most suitable with respect to pursuing coordination and uniform application of various sources and international instruments adopted or relevant, with regard to regulation of international trade relations (Schlehtriem, Schwenzer (eds.), 2010).

The criterion that must be applied to subtract the relationships they contemplate in unilateral regulatory assessments of the various national laws was fundamental in this regard. At the same time encourage acceptable solutions within the various states involved in them and/or within the framework of which their execution must take place. The interpreter must proceed to the determination of contents of such solutions framing them within a regulatory system different from that of a specific state.

It should be noted the need for the interpreter to free from categories and national legal experiences in order to seek an autonomous evaluation and interpretation of concepts and terms used in various instruments of uniform law in the awareness that often behind favorable frontal statements this approach hides solutions or choices that tend to make them coincide with those adopted in the lex fori. The interpreter 
must not be limited to formulations of principle but to identify choices with characteristics such as to be shared in other jurisdictions in ways that ensure uniform treatment of relationships governed by the discipline under examination in various state regulations. This must take place within the impassable limits posed by the expressions used in uniform law according to the satisfaction of specific needs regulated in it, i.e. internationality of its discipline and acceptability of choices fostered within the various contracting states.

Interpretive autonomy as a criterion aimed at freeing the uniform regulations of international origin from the influence of domestic law affecting its application

For some time there have been no uncertainties in affirming that the ambiguities and interpretative choices of various sources of uniform law discipline cannot be resolved on the basis of interpretation and contents of corresponding internal norms. Even in the presence of international normative instruments having a derogable content or formally becoming an integral part of various national legal systems which have adopted and introduced into them, it cannot be admitted that they are capable of being interpreted by means of an internal norm or on the basis of state order in which they must be applied.

The jurisprudence of states, although extremely jealous of their sovereign prerogatives and whose tradition tends to accredit the solutions matured in their sphere of international significance even in the English legal system, has long consolidated a line of thought by virtue of which interpretation of international normative instruments of uniform law relating to international trade precisely because they represent the outcome of an international conference provided an international currency. So the language of rules should be construed on broad principles of general acceptation. Identical principles have been in various places and repeatedly reaffirmed, also putting the evidence that the rules of uniform law relating to international trade must be interpreted taking into account their history origin and context. The need to impose a necessarily disengaged evaluation from the settings of a specific state system is also confirmed from this point of view. Only in this way can the harmonization desired by the legislation foreseen in instruments of international origin be achieved, due to the inevitable linguistic and conceptual compromises, which are distinctive of such international conventions (Jansen, Zimermann, 2018).

No doubt about the accuracy of what is clearly codified by art. 7, CISG on the need to employ techniques suitable for granting uniform law relating to international trade identity of treatment in each state system, preventing it from suffering at the time of its use resulting from the application of principles of each individual state.

No wonder on the other hand if in recent decades the law has tried to free the rules of uniform law regardless the regulatory force of the source of their origin and their effect, more or less derogable, from the influence of domestic law. I turn up their autonomy or specialty at the essential moment for their correct interpretative reconstruction. In this perspective it can be said that the indication of art. 7 CISG by virtue of which the interpretation and application of the present Convention (Schlechtriem, Schwenzer (eds.), 2010) will take into account its international character and the need to promote its uniformity. This means to codify principles that have found a large positive response in practical application and are extensible to interpretation of any discipline of uniform international law irrespective of the body that made it up and its imperative or payable nature. So much so that the most modern national systems of 
private international law have also endorsed these principles. It is often found that these are the criteria and interpretative choices of norms of uniform international law that shape the contents of corresponding internal regulations. This is how the normative contents of state law conform to principles established by uniform law, even if they have been derogated from parties and have no imperative effects on states.

Contrary to what happened in the past, it is on the basis of contents of these principles that the interpretation and application of state law concerning relationships governed by sources of international origin must be updated and clarified.

Identification and role assigned to "principles" underlying uniform law. The priority application of the analogue criterion

In the face of these certain and unequivocal clarifications, there are no clear indications that make it possible to identify in more operative terms the specific criteria to be adopted. In reality, the definition of more precise criteria is expressly provided for in art. $7 \mathrm{CIS}$. On the basis of these clarifications it has been possible to formulate further indications in order to give more concreteness and satisfaction to the requirement of which this principle is an expression. In particular, it was decided to inaugurate, evaluate, and integrate rules of uniform law relating to sale of movable goods on the basis of principles underlying CISG and by virtue of the analogical application of its provisions for which certain specific operational criteria were provided.

As part of these interpretative criteria, it has thus been specified that the reference (under article 7 CISG) (Schlechtriem, Schwenzer (eds.), 2010) to general principles on which the uniform regulation on sales is based, to favor an extensive application of specific provisions analogical interpretation contained therein which must therefore take place to the maximum extent. In other words, except of exceptional rules clearly indicated as not extensible to situations other than those expressly provided for, the analogical application of uniform law provisions relating to international trade must be understood as a primary instrument to provide for integration of their normative contents according to the specific needs and situations that arise in the practice of business even if not expressly regulated.

The usefulness of the aforementioned interpretative technique as well as the methods to be adopted in this regard has been found, for example, with reference to the place where the seller repays the price, following cancellation or termination of the sales contract. For this purpose, it was considered that the provision should apply by analogy of article 57, paragraph 1 (a) CISG of which the place of payment of the price in the performance of the contract of sale must be the domicile of the seller. Correspondingly, the restitution of the price must take place at the domicile of the buyer (that is, the person who must receive it). Especially since the identification of this place is confirmed by corresponding analogy (articles 57, paragraph 1 (b) and 31, paragraph 18,9 CISG) (Schlechtriem, Schwenzer (eds.), 2010) even if the price is refunded at the same time as the return of the asset object of sale.

The use of general principles underlying an international uniform law has been more complex when only the analogical interpretation of a specific provision does not lead to convincing results. In practice the discipline relating to sale has identified some references whose content often has characters very close to the analogical interpretation. To these the principle of which the seller of purchased goods is not liable 
with the provisions of commercial standards of the state of its importation, even if he is aware of his geographical destination. The rules of uniform and contractual law related to qualitative guarantees of goods bought and sold are limited to stock and within the framework of these principles. Any derogation to it has been considered admissible only if it is adequately expressed or justified by specific circumstances such as in cases where the same qualitative guarantee discipline exists even in the state of seller or buyer has specifically contracted the requirement of compliance with the state regulations of destination of good. (High Court of New Zeland, 30 July 2010, CIV, 2009-407-000363)

Criteria more markedly differentiated from analogical interpretation are those based on the need and principle of integration of various international instruments of uniform law in a direction aimed at simplifying the forms not only in the formation of contract but also in the event of modification and cessation of its effects. This is a principle that can be derived from the various regulations of different origins and brought to the base of international trade law and confirmed no more general definition of CISG regulations. So much so that it has been repeatedly used by the jurisprudence in order to avoid the analogical interpretation or the extensive application of few CISG provisions which, on the contrary, adopt formalistic criteria. Any exception to this principle in the context of international sale regulations was understood as exceptional (articles 12 and 96) (Schlechtriem, Schwenzer (eds.), 2010) and interpreted with restrictive effectiveness of its application. Moreover, the anti-formalist principle now indicated was not sufficient to consider a sale contract concluded by virtue of the simple delivery of the goods for which one party assumed that the relative sale was completed. (Handelsgericht Zürich, 22 December 2005, HG, 40371)

On the other hand, it did not hesitate to recognize the extensive scope of another principle underlying CISG regulations on the basis of which the seller can suspend delivery of the object of sale until full payment of the price. It has been recognized that the seller also has the right to suspend the return of purchased goods to the buyer in the event that the goods have been returned in order to provide for the elimination of defects reported in default of full payment of the related price. (District Court Arnhem, 29 July 2009). It was considered that this right, although not explicitly free, derives from the more general principle (the expression of which is articles 71, 73, 58.1 CISG) (Schlechtriem, Schwenzer (eds.), 2010) by virtue of which the suspension of seller's obligations is allowed until the full performance of service is due from the buyer. Principle that in international trade legitimizes, more in general, the suspension of main obligations in defect of the correct fulfillment of the correspondent ones foreseen charged to the beneficiary.

(Follows) Concrete identification of principles underlying the international regulatory instruments. Recognition value of Unidroit Principles and jurisprudential practice

In order to promote greater certainty and predictability in recognition of principles to international trade, it has been specified that they tend to be codified on at least coherent with those envisaged by Unidroit within the principles of international commercial contracts (Slater, 1998, pp. 232ss) whose scope and effects will be examined in the following paragraphs. And it is thanks to the same art. 7 CISG which has assumed a more precise circumstantial scope suitable to offer from time to time more predictable contents to integrative interventions of the specific uniform discipline related to the sale, bringing 
back and legitimating its scope precisely in virtue and within Unidroit principles. On the contrary, it can be affirmed that they have also made it possible to rationalize the interpretative outcomes of practice and common normative experiences of various state systems with specific regard to applicative principles of uniform normative of international origin.

Within this perspective, we note in particular the useful use of principle indicated in order to clarify the scope of favor contracts now considered as a principle applicable to any legislation of international origin that is relative to contractual relationships, specific solutions and concrete interpretative choices to preserve the contract, as well as to encourage the extension of cooperation obligation to which the parties are required to favor mutual contractual services including the obligation to take all reasonable steps to reduce the harmful consequences of any breach by other contracting party.

With specific reference to recognition function principles applicable to the discipline of uniform law relating to international sales Unidroit principles, a significant example is provided after an uncertain path to judges of the Belgian Supreme Court ${ }^{2}$. It was a matter of establishing unexpected circumstances occurred the delivery of promised item particularly burdensome (i.e. the sudden and exorbitant increase in production costs) to justify the application of art. 79 CISG (Schlechtriem, Schwenzer (eds.), 2010) even if its literal formulation indicates the impossibility of execution of performance as an exhortation cause of fulfillment. And above all it was necessary to clarify whether this provision could be integrated so as to allow the party whose performance had become excessively burdensome to request the adjustment of contract to circumstances arising from a renegotiation in good faith.

The supreme Belgian court, overcoming the uncertainties and motivations adopted by the judges, had no hesitation in affirming an interpretation of art. 79 to extend its scope by virtue of the principles underlying the uniform regulations concerning international trade and CISG for cases of supervening circumstances that are likely to significantly disturb the contractual balance with the provision to renegotiate the sales contract. The latter solution which found an important argument in its comparison in the content art. 6.2.3 of the Unidroit principles, precisely because they are relevant to integrate the scope of application and contents of the discipline in question also in virtue of art. 7.2. CISG (Schlechtriem, Witz, 2008; Dewez et al., 2011, pp. 102ss; Delebecque, 2016).

The possibility of integrating the contents of various uniform law norms relating to international trade is confirmed not only by virtue of the principles of them, flipped, specifically and directly obtainable, but also on the basis of the more general principles of international trade indirectly included in various regulations relating to the sector in question. In particular with regard to the principles relating to international contracts specifically relevant for integrative/interpretative purposes of various types of provision of uniform law applicable to international trade, it is confirmed that for their recognition can be usefully used in the context of Unidroit principles of international commercial contracts.

In the recognition and precise determination of these principles, the previous jurisprudence of various legal systems concerned with the application of specific uniform laws relating to international trade, regardless of their source and their operation, are 
particularly relevant. For the purposes of recognizing their content and their scope, Unidroit principles are relevant and usable for interpretative/integrative purposes to the extent that their authoritativeness emerges from a real apathetic applicativeness of a jurisprudential nature, especially if it allows to further specify the contents and/ or adapt them to particular requirements of the relevant provisions concerning the specific uniform discipline.

These precedents have to be standardized even if they may not be shared in terms of a different evaluation of the law to be applied in the specific case. In a very famous case concerning the interpretation of a uniform law (in the field of maritime transport), Lord Denning did not hesitate to highlight the operation of integrating the contents of uniform law according to common principles, the need to follow the results of foreign precedents when they are of jurisprudential origin: "(...) even if I disagreed" (Jansen, Zimermann, 2018). Precisely because it deals with a matter which is of international concern it is absolutely necessary that in this regard the courts of all countries should interpret the convention in the same way (Dewez et al., 2011).

No doubt about the essential role that must be assigned to the jurisprudential practice of the various states in the integration and application of the legislation in question, also as a source of recognition of the principles laid to its foundation. To this end, the unequivocal textual argument referred to in articles 31 (and in particular its paragraph $3 / b)$ and 32 of the Vienna Convention on the law of Treaties, where it specifies the particular scope that must be assigned to the application practice in the interpretation of rules of conventional origin and more specifically in order to identify the principles that can sometimes be derived from the specific norms of uniform law. It is a very valuable interpretative element not only for the purpose of determining the precise scope of each expression used in the legislation under examination but also in identifying the specific ratio and principles applicable to the various legal systems of uniform law relating to international trade relations to guarantee the identity of data processing and related reports within the various legal systems involved in their execution.

The specific relevance of application practice. The progressive enlargement of its scope and sources of its contents

In addition to jurisprudential the applicative practice also underlines a different profile for the purpose of integrating and interpreting the discipline of international origin relating to international trade. This is any other act or behavior of states that allows the emergence of their consent to emerge on a certain assessment of ambiguous aspects or of uncertain interpretation of uniform law. To this end they will be able to identify the declarations or behaviors attempted by the states not only during the elaboration of a specific uniform law (through the so-called preparatory works) but also during the formation of other norms concerning international trade and in particular of those interfering with the execution of various reports related to it. In these circumstances it can be verified that the states indicate without uncertainty to favor a specific interpretative choice of the various regulations and in particular of some notions used in them, demonstrating unanimous consent (or at least consensus) in this regard.

In this perspective, the indications emerging from the decision of International Court of Justice (Costa Rica v. Nicaragua case of 17 April 2013) seem particularly significant, specifying the ways in which the interpretation internationally oriented by the rules of uniform law must be realized (with specific regard to those relating to international trade). It should be noted that the expressions used therein must 
be interpreted taking into account not only their literal significance at the time of their approval and preparatory works but above all of the meaning assumed at the time when the question concerning their application arises. It is recognized that in a uniform discipline of international origin, the expressions used must be assigned a meaning not already crystallized at the time of their formation but susceptible to change over time on the basis of the evolution of the content which progressively establish itself by virtue of the practice in the international arena.

With specific reference to the notions employed by various norms of uniform law it must be considered that they must be interpreted according to the evolution matured at the time of their application taking into account the significance they progressively assumed within the various disciplines elaborated with regard to international trade and not with exclusive reference to those existing at the time of preparation of the relevant discipline of belonging. These indications also confirm, from this point of view, the consequent and evident loss of relevance of the preparatory works in the assessment of the extent and effects of uniform regulations of international origin concurrently with the valorization of the scope of application practices to be understood as including all the indications emerging from the various types of uniform law gradually adopted with respect to international trade. Indications that can be usefully exploited also by virtue of the evolution of the contents of various expressions and notions that are established volatile at various international venues in relation to international trade as well as in the social sphere of material recipients of such regulations.

It is advisable that through the extension of the scope of application practice, adequate relevance is also given to the use of a fruitful interrelationship between the outcomes of the solutions that have actually been adopted in the numerous provisions of uniform law provided in the various sources of knowledge relevant in this regard and in the specific codifications of normative uses that in different ways affect the execution of international trade. In this perspective we must point out the progressive and important role related to the usefulness of mutual reference and to the continuous interaction of the application practices related to the various uniform laws as occurs with regard to international sale of maritime transport with specific regard to the relevant moment to determine the place and time of delivery of goods being sold or the time of transfer of risks of losses or damage to goods from the seller to buyer in addition to the provisions of articles 66 CISG and following.

In this way, a more and more marked need is felt and confirmed in order to bring the discipline of international trade relations within the parameters of a real regulatory system on the basis of which the common requirements underlying this phenomenon are based on criteria that can be derived from the evolution of notions and various choices adopted in different legal typologies of uniform, hard and soft law that progressively establish themselves internationally.

Also from the point of view indicated above it is confirmed that art. 7 CISG must be understood as a paradigmatic example of the need for an increasingly accentuated interaction between the various types of uniform law regulations relating to international trade in the search for concrete interpretive choices (Schlechtriem, Schwenzer (eds.), 2010). When the analysis of a text does not lead to safe choices and no convincing results emerge from the applicative practice or from the possible presence of specific principles underlying the special legislation proper to a particular international trade relationship, they are only reciprocal references and interactions between the various disciplines and types of uniform law relating to international trade in their continuous 
evolution and concrete implementation that can make an important contribution to the definition of contents of relevant regulations.

Good faith in international trade between uniform law and contractual discipline The reference of art. 7 CISG to the observance of good faith on the occasion of interpretation of the norm of international commerce and extension of its operativeness to every normative uniform law. In reality, this is a normally non-recurrent criterion in the provisions concerning the interpretation of rules of uniform international law but rather a parameter relating to the behavior that the parties must take in the formation and execution of contracts or relevant for the purposes of interpretation of contracts.

Such circumstances and ambiguities that the mention of good faith in art. 7.1. CISG confirmed by the same preparatory works that preceded it. Many proposals had been made with express reference to the seat and modalities for the insertion of good faith in the text under examination. Some aimed at favoring its use in interpreting the declarations and behavior of contracting parties. Others by virtue of which good faith had to be foreseen in order to clarify the standards of conduct to which the parties had to consider themselves bound.

It was decided not to take a precise position among the various proposals and to adopt a compromise solution that led to the use of good faith in the interpretation of uniform regulations on international sales according to the formulation of art. 7.1. CISG, in order to interpret the rules of uniform law taking into account the need to promote the observance of good faith in international trade (Komarov, 2005, pp. 76ss).

This choice is justified not only for conceptual linguistic compromising needs typical of the drafting of uniform regulations but also for the specific characteristics related to the use of good faith when the relevant discipline is largely dependent on private autonomy being reserved to a very extended device power compared to the corresponding regulatory contents. It was considered that the reference to good faith with regard to the rules of CISG uniform law should be placed on the same level as the interpretation of the specific contractual clauses relating to the contract of sale of movable goods that can be implemented by way of derogation or completion of this legislation as well as the determination of the behaviors that, by virtue of the consequent discipline, must hold the parties during the relative negotiations and the actual execution of what was agreed or of what emerges from the application of the legislation in question (Felemegas, 2007; Ferrari, 2011).

In regard of good faith principle, it was established that the seller could assert the contents of his general conditions, to which he had referred only if he had proved to be the buyer in the condition to know them completely and promptly in their scope and in all their contents. It is considered to be the case for the purchaser in any other case assuming that it is obliged to carry out specific investigations with the consequent risk and disadvantage of operability conditions unknown.

In other words, acquiring the risks and disadvantages arising from the operation of unknown conditions to the seller without their content faith ${ }^{3}$. Equally significant is the Spanish sentence in which the application of the principle of good faith under art.7 it has been clarified that the complaints related to the products bought and sold as well as the possibility to provide the appropriate justifications or corrective actions order to replace them ${ }^{4}$.

3. Oberlandessgericht Celle, 24 July 2009, n. 13 W48/09 and Oberlandgericht München, 14 January 2009, n. 20 U3863/08. 4. Court of Saragoza, 31 March 2009, Westlaw, 221573/09 
In this sense, good faith is the interpretive parameter that links the criteria to other relevant regulatory sources and clauses provided for the various international contracts and individual contracts of purchase and sale as provided for in articles 8 and 9, CISG (Schlechtriem, Schwenzer (eds.), 2010). And it is precisely by virtue of this connection that the application of a specific use, even if provided with the requirements of art. 8, lett. $a$ and $b$ CISG when it results in virtue of the specific characteristics of the contractual program of a particular sale, contrary to good faith in international trade. As has been noted with regard to the assessment of the applicable discipline to an international trade contract, the interpretative/integrative choices aimed at encouraging solutions consistent with uses are certainly to be favored provided the fundamental requirements of justice in international trade and the concept of good faith in business ${ }^{5}$

Article 7 CISG codifies the criteria by virtue of which it is possible to select the interpretative choices to be made between the directives expressed in the legislation of uniform law in favor of private autonomy (article 6) and the sources of international origin concretely referring to the various relationships of international trade and in particular the different types and methods of buying and selling (Janssen, Meyer, 2009). It is pointed out that in this perspective the composition of various regulatory sources must be made by valuing as much as possible the program and implementation must be evaluated in good faith. Faced with the plurality of additional sources relevant to this discipline and to the heterogeneity of the normative material indicated in articles 7,8 and 9 CISG to good faith thanks to its location in art. 7.1. CISG (Schlechtriem, Schwenzer (eds.), 2010) is entrusted with the task of providing for their correlation and coordination with the provisions in favor of the exercise of private autonomy in the previous art. 6 . The simple application of these rules is excluded by virtue of a mechanical hierarchical relationship between them and the need for a more complex interpretative and integrative operation of the contractual relationship is specified. Good faith takes on a specific importance as a benchmark evaluation parameter addressed not only to the contractors in determining their behavioral rules in the formative and executive phase of the sales contract but also to judges as a reference model for their decisions regarding the evaluation of mutual claims of the contractors and the justification for the non-execution of respective obligations regardless the normative, conventional or customary source by virtue of which they are invoked.

Good faith and limits to its use

In order to avoid excessive arbitrariness of the judge in the integrative and interpretative use of good faith with respect to the role reserved for private autonomy by art. 6 CISG and to use the other criteria indicated in articles 8 and 9 CISG, art. 7 makes it possible to identify at least some parameters of judgment that make it possible to orientate the evaluations. Also in this regard the criteria referred to in the preceding paragraphs must be used, among which the one relating to the use of the applicative practice and above all of the jurisprudential practice to which a specific importance must be assigned in determining the concrete ways of using good faith that allow to limit and control the discretion of the judge and to make the relevant decisions predictable.

But not only will judicial practice be relevant to the purposes indicated above. Importance must also be reserved for contractual practices, especially when they are so common that they are almost normative in nature. It will have to deal with typical

5. Court of Appeal, 20 July 2009, 209, EWCA CIV, 755. 
commercial formulations commonly used and habitually recurring in the contractual practice that it is reasonable to believe, are known and accepted by the parties. In other words, the contents of international uses and objective rules of international trade, as well as any other source of soft law, may be used for integrative/interpretative purposes of the discipline various international trading relationships as a component of their application practice which also detects their assessment and evaluation of the behavior of the parties contractors in good faith.

As indicated above, CJEU jurisprudence in case: C-87/10, Electrosteel Europe SA, is also authoritative. In fact, the Advocate General Kokott has not hesitated to state that place identification of a purchase contract must take place in virtue of a pragmatic determination without entering into complicit matters of law by viewing consultable rules that are explicitly indicated in Incoterms as consolidated uses, specified and published by recognized professional organizations and widely followed by economic operators in non-state regulations of international trade.

The use of good faith can also justify the imposition on parties of additional behavior with respect to those provided for by contractual and specific provisions of international uniform law beyond their formalization in blush or soft law instruments. Consistency must be consistent with the principles underlying the legislation which is sometimes relevant as specified in the preceding paragraphs and with those that express the function and relative values characterizing specific contractual relationship by virtue of discipline actually desired by the contracting parties. Are these values and principles that constitute the point of reference and limits within which good faith can operate in the meaning indicated by art. 7.1. CISG (Schlechtriem, Schwenzer (eds.), 2010).

Interventions integrating norms of uniform law according to the protection of public needs of states or of the same uniform law

Any supplementary intervention external to the area now indicated as a function of protection of social solidarity's values cannot be generically justified by the principle of good faith but only by other principles related to special legislation relevant or operating in international trade law. In this direction it will be possible to operate in the case of interests whose protection concerns public order of various states involved in the performance of contract or whose significance and effects are foreseen by specific norms of uniform law with binding contents that interfere with execution of international trade relations. In particular, these are cases in which the performance of obligations deriving from a contact relating to international trade is prevented by a provision of one of the states in which the relevant conduct must take place or by the importance of the necessary rules of third states referred to in it must be taken into account by virtue of the principles of private international law applicable to the integration of uniform legislation (Garro, 1994/1995, pp. 1150ss; Di Mateo, 2014).

In this respect, we consider of state regulations concerning customs or foreign exchange controls and their relevance and impact on legislation applicable to international sales. On the other, the need for such regulations to guarantee compliance with the related effects, with consequent integration of the rules applicable to the execution of various international trade contracts, have clear traces to some articles of CISG. Article 54 foresees among the obligations of the buyer not only the payment of the price but also the fulfillment of all those acts required by the applicable laws and regulations to make such payment possible in favor of the seller. This certainly includes and underlies the obligation to pay homage to rules on exchange rates as 
well as administrative rules concerning the import or export of certain categories of goods. In this way the relevance and need to integrate its effects in the uniform law and regulation of the contract is recognized.

In the same sense, we cannot fail to take into account and apply the discipline of intellectual and industrial property which recognizes the need to observe the regulatory content in the respective areas of operation while limiting in this regard the guarantees of the seller to the sole existence of claims relating to third (intellectual and industrial property) rights over the items to be sold under the provisions of law of the state in which the goods are to be used or resold or alternatively of the vineyard regulations in the state in which the buyer has his own operational center (art. 42).

Under this last aspect, even the norms of soft law of uniform international law with a derogable content are not insensitive to the presence of aspects of international trade in relation to states intervention with rules of particular imperative or publicist intensity. On the contrary, we are concerned to recognize the uniform law regulates the effects directly, indicating the behavior to which the parties are tenuous or consolidating them the integration/interpretation required in this regard according to the specific nature of characteristics and contents of various contracts.

Legal regulations and residual integrative rules of private international law: Results and perspectives

Despite the nature of uniform law, the importance of state law is not excluded for the purpose of integrating the discipline and the related contractual regulation. These are cases in which the interpretative/integrative techniques of the uniform normative do not allow to arrive at a solution endowed with the characteristics of reasonableness and predictability. In this situation, there is a need to adopt a residual choice in the face of impossibility of a uniform interpretation of the legislation in question due to the presence of unattainable gaps by virtue of the application of the principles that can be derived from it or the use in analogy of good faith. This choice is once again directly operated and expressly recognized by art. 7.2. CISG which in this case provides for the use of rules of private international law. The application of the state legislation identified by virtue of the connection criteria adopted in them (Smith, 2011, pp. 2ss).

CISG in question confirms the unrecognized relevance of solutions similar to those provided for by art. 17 of "loi uniform sur la vente internationale d'objets mobiliers corporels (LUVI)/uniform law on the international sale of tangible movable objects (LUVI)" (Smith, 2011, pp. 2ss) and above all favored by the interpretations in this regard formulate by virtue of which, in any case, the gaps of uniform discipline must be solved only through the use of its principles and name provided therein (Schulze, 2009). In this regard, contrary to this solution, the fact that this excessive and exorbitant use of general principles or analogical interpretation (beyond the ratio and scope of contents of the specific provision) lends itself to allowing an excessive margin of discretion has proved decisive to the judges who, in addition to the uncertainties that ensue, have even led in fact to a return to privileging the nationalistic solutions of the lex fori where there is a gap in uniform law.

The unavoidable use of rules of private international law which, by the way being characterized and applicable to contractual relationships by a substantial homogeneity of contents of the various national legal systems, are able to guarantee even 
through a different technical uniformity solutions with greater probability of success than an excessive and uncontrolled recourse to analogy or general principles. In this sense, the residual use of rules of private international law does not seem to represent an effective danger to the progressive development and to the affirmation of uniformity of the discipline of relations concerning international trade. The results obtained in this regard through the extensive information and use of interpretative technique based on jurisprudential practice and exchange of mutual experience gained in the various jurisdictions to fill directly or indirectly through converging solutions of private international law, some of the various uniform organ and international regulations highlight the conclusions now indicated. The progressive enrichment thus achieved by the solutions adopted to ensure a uniform interpretation of these regulations must be noted by virtue of the aforementioned technical specifications including the additions made by virtue of the application of rules of private international law.

A particularly significant example is that relating to the regulation of conversion rate of the sale price or interest rate due to sale price not promptly paid. In both cases it was recognized that the elation discipline should be determined by virtue of the applicable name of private international law, having been unanimously found that there are no specific provisions or principles applicable under the various laws of international law. But this is not only. This discipline has been concretely identified in most cases and according to the employment of convergent linking criteria that have led jurisprudence to favor uniform normative parameters foreseen in seller's law.

In this sense, a Dutch decision was expressed ${ }^{6}$ that recognized the operability of rules applicable under the provisions of private international law also for the specific purpose of determining whether the imputability of payments should take place on the basis of eligibility to various relationships attributable to the purchaser. On the occasion of residual use of private international law with regard to regulation of payments, it has not been hesitant to confirm the relevance of law of the seller to the latter in virtue of common provisions of Community origin relating to the law applicable to contractual obligations.

It is thus confirmed that the use of private international law brought back to its function within the precise and shared limitations is suitable to lead to solutions concretely converging in the various systems guaranteeing and completing the uniformity of substantial discipline of international trade relations also for those aspects for which there is a lack of rules directly or indirectly attributable to them.

"General principles" relating to international trade and their codification in soft law instruments

From the characteristics of various types of regulations developed by international trade law, it is clear that relative contracts must be assessed according to the particular environment in which the operations that constitute the foundation of both the various territorial areas within which they operate and domiciled the relative owners of those assets are found the effects of these operations. Above all it emerges the ample space is reserved to the exercise of private autonomy and operativity of various international normative texts often of a soft law nature. In both cases it is thus possible on the one hand to avoid conceptual and regulatory references specific to a state system and to adopt solutions widely accepted by national legal systems and practice of international tribunals contained in the perspective to the particular needs of the operation underlying the contractual relationship to its characteristics and to those desired by 
the contracting parties taking into account, in particular the location of execution of the relationship and the context in which the prevalence of the relevant interests in this regard is significant.

It is in function of them that adequate emphasis is given to principles or normative solutions according to contents not necessarily referable to a type or a nomen belonging solely to the culture and tradition of a specific order. We are concerned with adopting specific definitional contents of the expressions used according to the particular perspectives in which they must be used, also taking into account the elaboration of international standards of uniform law and spontaneous indications of practice (case law and applicative) relating to the presence of general legal rules and principles common to various legal systems according to what is detectable in international legal life. This derivation also makes use of various codes of soft law regulations elaborated at international level, and some results achieved in studies and researches promoted by specific international organizations or bodies of an intergovernmental nature or associative composition among representative subject and the various interests involved in international trade.

These defining principles and contents in particular are usefully used as a valid support for the drafting of international contracts not only for identifying the aspects of discipline to be adopted according to objectives pursued by parties but also for providing a legal terminology which is basically neutral as well as clearly perceivable and shared internationally in its contents intentionally used independently of the culture and experience gained with regard to these expressions in legal systems in which they were originally adopted.

(Follows) The importance of Unidroit principles and their use through the faculty of parties to choose the "rules of law" applicable to their contractual relationships

In the perspective indicated above, they play a very special role the principles adopted by Unidroit, which also offer an organic reconstruction of the set of principles and rules to be unmoored from the culture and experience of a single and specific legal system from which they do not claim to receive legitimacy and binding force. This organic discipline of definitions, principles and rules is addressed and made available to the parties to international contracts in the knowledge that it is not a binding instrument and that its acceptance depends on its persuasive authority as explicitly indicated by the governing council of Unidroit already on the occasion of introduction to the first edition of Principles. This acceptance was immediately and repeatedly manifested in various locations and within the discipline of many international contracts. The Principles found consents and specific acknowledgments so authoritative and repeated that at their last edition, the Governing Council was able to express its confidence at international legal and business communities to which the principles were benefit from their use.

This use of Principles has undoubtedly been favored by the adhesive attitude to their use both by the subjects who are interested in international trade operations and by the arbitration practice whose effects have been consolidated through the ever wider recognition in state bodies and regulatory systems of uniform law the role of private autonomy and effects of international commercial arbitration in the context of international contractual relations (Bergè, Francq, Gardenes Santiago, 2015; Waincymer, 2012, pp. 5ss). 
It is not surprising that the value and scope of the various manifestations of private autonomy have been greatly emphasized since the first article of the Principles, also on the basis of a substantial legal right, as already indicated in the preamble with a view and by virtue of international private techniques. At that time it is precisely through these techniques that the procedures through which private autonomy can be used to make the Principles applicable to the maximum extent possible: that is, by virtue of the express choice of the contractors to the principles exclusively referred to full effectiveness and guaranteed if accompanied by an arbitration agreement (Wautelet, Kruger, Coppens, 2012). The same provisions in force in the various state systems and in numerous regulations adopted by the various arbitration chambers concerning the international commercial arbitration provides that the parties are authorized to choose the solution of relative disputes on the basis of rules of law not necessarily referable to a specific state system (Luttrell, 2009. pp. 64ss; Aksal, 2011, pp. 158ss; Laird, Sabqhi, Sourgens, Weiler, 2015; Kjos, 2013, pp. 123ss). It even favors the exclusion of application of any state system except for some provisions of legal systems endowed with such intensity and normative force to be imposed in each case according to their content and connection with some aspects relevant to the settlement of dispute.

It is precisely in line with what is now indicated that, by making use of the indications coming from the same parties involved in resolving a controversy, the arbitration rulings apply those general principles and rules of law applicable to the international contractual obligations business community. It is noted that by freeing the parties from the need to apply a specific national system, they are allowed to use those rules of law and notions that are deserving to be qualified as being general accepted ${ }^{7}$. So much that in an important convention of private international law it was expressly stated that national judges must also take into account when there are indications of the parties, the general principles of international commercial law recognized by international organizations without the necessary intermediation of any state system.

And in the same perspective, par. I-203 of the Uniform Commercial Code recognizing the right of the parties to change any provision that is not expressly provided for the non-disclosure admits an incorporation by reference of non-states rules and in particular those provided in the recognized bodies of rules or principles that the comment in par. I-201 must also extend to non-variable rules provided for in this regard (Kroenke, 2000, pp. 14ss; Bonell, 2006). At least in a state legal system (that of the State of Oregon) in the official commentary of international norms of private autonomy, it is specified that this autonomy, parties may select model rules or principles ${ }^{8}$ especially those relating to the right of international trade. And similarly, even if in less precise terms it is expressed or in any case was understood by its more qualified interpretation, art. 3540 of civil code of Louisiana when it provides for the application of law expressly chosen or clearly relied upon by the parties precisely because it was intentionally wanted to avoid the term law by limiting its scope attaching it to a state or country. It is considered that the legislation of Louisiana would not enforce the parties' right to comply with the public policy of the state whose law would be otherwise applicable (Symeonides, 2006, pp. 210ss; Saumier, 2014). 

judges

On the other hand, the parties in the exercise of private autonomy may resort to the choice of principles and rules of law not necessarily due to a state legal system is confirmed by the regulatory trends matured internationally in this regard. Suffice it to recall the latest approval of the Hague Conference of Private International Law. In the preliminary document drawn up in January 2012 in preparation for the council session for the adoption of the related policy document it was agreed that the choice of the parties concerning the applicable law. In this sense, without a specific limiting definition of this notion, a meaning of rules or law has been adopted in favor of ensuring the maximum support for party autonomy with the sole indication that the chosen rules of law must be distinguished from individual rules it must consist of a body of rules.

And it is probably precisely because of the evolution that a part of the doctrine had no hesitation in proposing an interpretation of the Rome I Regulation (CE No. 593/2008 of 17 June 2008) ${ }^{9}$ that while recognizing the limits set by art. 3 to the possibility of choosing rules of law not belonging to a state system such as the Unidroit principles and the non-traceability of this reference to the category of true and traditional choice of law clauses does not exclude the operation and effects emphasizing in this regard also the scope of the thirteenth recital of the Rome I Regulation. It is noted that the same state regulations and in particular those in Europe provide that the interpretation and integration of contracts must take into account the true intent of parties. In this perspective, it is not possible to state that it is not possible to disregard the deferral made by the parties to a body of rules when they are elaborated by international bodies specifically qualified according to the results of the practice and in line with the requirements of various applicable state regulations. It should be added that precisely by virtue of these characteristics, the relevance of rules of law is also justified in this respect, since they are unlikely to be in contrast with mandatory rules of legal systems applicable pursuant to art. 4 of the aforementioned Rome Regulation in defect of the conventional choice of a specific state system.

This is a solution that is very close to that which in the previous paragraph has been expressly codified and shared within the inter-American system of private international law, in which the obligation of judges to determine the discipline of international contractual relations is also stated in general principles of international commercial law recognized by international organizations ${ }^{10}$.

In the opposite direction, it has been observed that the deferral or choice of parties to regulate their contractual relations by virtue of a reference to rules of law not necessarily related to a state order must be classified in a particular type of negotiation incorporation of the regulatory content of such rules. It is acknowledged to be an operation and effects superior to a mere postponement only within the scope and effects of contracts, but it should be noted that in this case an applicable law must be identified to be chosen by virtue of a further indication made by the parties, or in view of the relevant connection criteria in the absence of a voluntary indication of the

9. Commission Regulation n. 593/2008 on the Law Applicable to Contractual Obligations (Rome I), 2008 0.J. (L 177) 6. See the next cases from the CJEU in argument: Verein für Konsumenteinformation v. Amazon EV Sàrl C-191/15 of 28 July 2016, ECLI:EU:C:2016:612; S. Kareda v. S. Benkò C-249/16 of 15 June 2017, ECLI:EU:C:2017:472; Höszig Kft v. Alstom Power Thermal services C-222/15 of 7 July 2015, ECLI:EU:C:2015:525; K Finanz v. Sparkassen Versicherung Ag. Wien Insurance group C-483/14 of 7 April 2016, ECLI:EU:C:2016:205; H. Lutz v. E. Bäuerle C-557/13 of 16 April 2015; Mühlleitner v. Ahmed Yusufi \& Wadat Yusufi C-190/11 of 6 September 2012, ECLI:EU:C:2012:542. All the cited cases was published in the electronic Reports of the cases. For more details and analysis see: Kramer, 2015, pp. 250ss; Calvo Caravaca, Carrascosa Gonzàlez, 2017, pp. 106ss; Brand, Fish, 2008, pp. 302ss; Carruthers, 2012, pp. 881ss; Okoli, Arishe, 2012, pp. 516ss; Kroll-Ludwigs, 2013, pp. 573ss; D'Avout, 2010, pp. 184ss; Dannemann, Vogenauer, 2013, pp. 16ss; Mcparland, 2015; Wais, 2017; Liakopoulos, 2018; Andrews, 2013, chapter 22; Ballestros, 2014, pp. 292ss; Boele-Woelki, Einhorn, Girsberger, Symeonides (eds.), 2010, pp. 564 ss.

10. Art. 9.1. of Convention of Mexico of 17 March 1994. 
parties. In any case, this choice must be made consistent with the aforementioned reference to the rules of law and their regulatory contents, which will be guaranteed in this perspective as effectively as possible. It is certainly also according to this last approach that, regardless of the solution to be preferred among those mentioned above, the reference to rules of law chosen by the parties may be effective as it is made in favor of a regulatory system of international origin endowed with a tendency completeness with respect to the subject of its discipline as well as characterized by principles that allow adequate integration and interpretation.

Both of the aforementioned settings are characterized by the common concern of ensuring an adequate regulatory framework for the rules of law directly chosen by the parties. The reference to them will be all the more effective the more these rules, even if not identifiable with a state system, can be endowed with the character of a true internationally uniform positive legal system that regulates in a tendential manner the discipline of contractual relations to it attributable and in respect of which any supplementary intervention he statutory orders is residual if not justified by public order requirements.

In this sense, private autonomy turns out to be an essential tool to guarantee effectiveness to norms of international origin belonging to the soft law. And this effectiveness will be all the more assured as the rules in favor of which the parties are postponing can be considered as an organic regulatory system with its own principles at least with specific regard to regulated relationships.

The exercise of private autonomy and the use of rules of law of international origin In the logic of normative evolution indicated above, clearly inspired by a liberal approach to relations and international trade that favors the autonomy of parties in the context of globalized commercial relations, it is natural that private autonomy and consequences of contract including freedom of parties in designating the rules or law governing their contract are confirmed by the Principles as the cornerstones of an open, market oriented and competitive international economic order (article 1). It is above all these freedoms that allow both parties and their interest to pursue purposes (and to obtain as far as possible the production of effects) of a material nature according to the economic reasons underlying the operation of which the contractual relationship constitutes formalization in legal terms. On the one, they are deemed to allow the parties to obtain the desired advantages through the choice of a specific discipline and rules of law applicable to a specific contractual relationship by virtue of which they have arranged to frame the related economic operation according to their specific negotiating intent. On the other, it should be noted that it is also possible to achieve the maximum efficiency of international trade by ensuring the rational placement within the international economic system of the results achieved by the parties and allowing the community of their respective membership and the entire partner environment.

The irreplaceable role played by private autonomy in the broader and more meaningful understanding of this expression according to the mentioned contents of the preamble and art. 1 of the Principles confirms, the ever-greater difficulties recently found and shared in doctrine, of clearly separating the effects and the operation of the exercise of private substantial autonomy compared to international privatistic one. It is found that the will of contracting parties is destined to operate as a regulatory factor in the contractual relationship with the result of substantially convergent objectives in all cases in which it indifferently operates as a criterion of international-private 
connection, or as a direct source of substantial discipline or is used through clauses of choice (or exception) of rules of law of international origin. And in this last perspective, in particular, it is confirmed that state regulations should not be considered the only ones to be reconstructed in the regulation of contractual relationships that can be increasingly filled with contents also through other reference regulations, among which, in particular the aforementioned non-state regulations or the rules of uniform law, which even sometimes expressly provide for the possibility for the contracting parties, to voluntarily extend the scope of application.

What now indicated does not in any way legitimize private autonomy as having the power to self-oblige and model international contractual relations by virtue of its own power that is the creator of legal reality. And in particular we specify how "contrat sans loi" is only a theory aimed at overemphasizing the regulatory potentialities of private autonomy. It is not only in the exercise of private autonomy that the foundation of the international contract is justified and guaranteed to be effective even when it appears to be self-sufficient. It must take over and receive legal legitimacy in the context of an order system.

Yet it is increasingly common practice in international trade contracts to use editorial criteria aimed at constructing a complete and self-sufficient regulation and on the other delocalized and internationalized it without any reference to the necessary intermediation of a reference system. So much so that in this case the Principles are concerned with ensuring that the discipline in question is consistent with the effects desired by the parties, being able at the same time to benefit, even in the absence of any specific indication on the subject by the parties, of integration and classification of such effects in a normative system adequately accomplished in such a way as to allow private autonomy to be realized to the maximum extent possible to the correctness of the formative conduct of the will of the same contracting parties.

This regulatory framework of private autonomy can therefore also be carried out by virtue of the recognition of the effects desired by the parties through the choice of transnational principles contained in international soft law instruments related to international trade. This technique is used more and more frequently and now generalized, which as indicated in the previous paragraph can produce the maximum effectiveness on the occasion and in the context of disputes relating to international contractual relations entrusted to arbitration solutions. It is precisely the national and international regulatory texts relating to international arbitration in order to legitimize with particular expressive intensity the direct employment, by the contracting parties and arbitrators, of rules and principles of substantive law adopted internationally, especially in cases where they are governed and ordered according to the criteria and modalities of a real and proper regulatory system contracts or specific aspects related to them without any necessary intermediation of a specific state system.

(Follows). Solutions adopted in Principles and in recent international regulations concerning international trade in favor of the application of overriding mandatory rules of state origin.

Recognition of the role and freedom of contractors to enter into contract and determine its content (article 1.1), even if with methods and contents indicated above, does not mean Principles' adherence to the settings they attribute private autonomy, a normative force that allows it to be independent from a classification of the contractual relationship in an adequate regulatory system. It confirms the impossibility of configuring 
the existence and legitimacy of contracts sans loi which are only the result of excesses of dogmatic reconstructions inconsistent with the effectiveness of the practice. On the contrary, the Principles aim precisely at facilitating this classification of contracts in an adequate and complete normative system in clear antagonism to the vision of a will which has in itself the force and creative power of juridical reality. The autonomy of the parties cannot in itself define the configuration of the formative conduct of an international contract, to which the Principles allocate considerable space and great importance for this reason.

It is true that private autonomy in and through the referral to Principles, as well as to other norms of international and/or non-state origin, characterized by their soft law nature, is able to configure and regulate international relations, operations according to the most suitable methods with respect to the negotiating intent desired by the parties. And it is equally true that the recognition of other regulatory potential of private autonomy, also in order to guarantee the enforceability of international discipline of soft law instruments, largely takes into account the Principles, enhancing their effects according to criteria that tend to lead various indications in this regard through the use of different institutions and/or concepts can be derived from the different legal traditions of the various legal state systems.

This recognition of the role and potential of private autonomy, also in order to guarantee the maximum effectiveness of the international normative expressions of soft law, does not in any way imply its absolute pre-eminence with respect to the discipline of Principles and state legal systems endowed with particular links with the contractual relationship, especially that in which the effects must be realized. It is only through compliance with some particularly relevant rules in these laws and in the same Principles that it is possible to fully achieve and in every order in which they must be obtained, the effects of the contractual relationship with guarantees of effectiveness of the choices made by the parties in favor of the same rules of law of international origin to which a direct referral has been made.

On the other hand, the ever clearer and more unequivocal expressions of the more recent codifications of private international law indicate that the choices of the contracting parties concerning the rules applicable to international contracts can take place through various modalities so that their effects can be precluded only when and in the extent to which they lead to results that arise or are in contrast with the principles of international public standards of the lex fori or in specific circumstances with the necessary application rules of any other system with which the regulated situation has a close link. With the clarification that the characteristics, the nature and the effects of every aspect of the contractually regulated situations must be considered in relation to the evaluation intensity and to the connection with the state norms that are intended to be applied in derogation of the effects desired by the parties. These profiles must be carefully taken into account in the knowledge that in the absence of the realistic assessment now indicated the application of rules belonging to third party coordination with respect to (or in competition with) the substantial discipline desired by the parties and the order they choose or otherwise destined to regulate the contractual relationship risks to undermine the same regulatory properties of the contractual relationship making them lacking in concrete impact in practice.

As indicated above, specific references to legislation have already been found in the Rome Convention of 1980 (article 7), partly reproduced and better specified and even in a reductive sense in Rome Regulation I (article 9) which codifies the need to take 
into account in determining the rules applicable to contractual relationships not only the choices made by the parties including the reference to international soft law regulations but also the necessary application regulations not limited to those provided for by lex fori or lex causae but also extended to third states with qualified links to the contractual relationship. The judge or the arbitral tribunal is allowed to give an application even if within precise boundaries and after adequate assessment of the various aspects indicated before to states norms different to those of the forum or order chosen by the parties even if they are third not EU countries.

It is certainly true that, in the face of various indications and legislative proposals, the Rome Regulation I (article 9, paragraph 39) has decided to clarify and limit the effects of third states provisions only to legal systems in which the locus executionis arises (Liakopoulos, 2018).

But it is also true that, on the basis of the same indications of international commercial arbitrations, even in the most widely recognizable cases, of a large space for private autonomy and in which great importance has been assigned to non-state norme in the discipline of international contracts situation to highlight the precise need to take "en compte des lois de police and the appliquer de manière consciencieuse on the basis of critics aptes à apprivoiser les exigences des Etats" (Liakopoulos, 2018). It is thus the same practice of international trade that recognizes the need to take into account in the evaluation of the discipline applicable to international contracts as well as the spaces to be assigned to private autonomy, including rules in force in states laws with which some aspects of contractual relationship is strictly linked by virtue of their particular intensity of assessment, regardless of the state or non-state regulation governing the contract even if they do not belong to the lex fori.

Referral to body of rules of international origin and the presence in their sphere of mandatory norms and principles.

No wonder even if the Principles have shared this requirement by providing art. 1.4, a specific provision in which it is excluded that both Principles and regulation of contracts concluded on the basis thereof are not intended to prevail on the mandatory rules of domestic law, or of national international or supranational origin and in particular on the specific statutory provisions and on the relevant general principles of public policy. That is, the Principles and the relative contractual regulation cannot prevail over the imperative rules that cannot be waived by parties' will (i.e. ordinary or domestically mandatory rules) envisaged by the lex causae which may be deemed applicable to the contractual relationship when the dispute is deduced before a state jurisdiction. On the other hand, in any case and in particular also when there is an arbitration proceeding at least on the mandatory overriding of the state of the forum or of third states in the presence of an adequate intensity of links between these provisions and the contractual relationship.

In other words, when a dispute must be resolved before ordinary jurisdiction, Principles and related contractual rules meet the limits of mandatory rules intended to prevail over the will of the parties by virtue of the provisions of lex causae. If the dispute is to be settled before an arbitral tribunal, it will be possible to indicate and allow Principles to be directly applied without any intermediation or restrictions by the state system otherwise applicable to the contractual relationship by virtue of what is expressly provided by almost all the provisions of the various regulations adopted by the various arbitration chambers in order to regulate international commercial arbitration 
and by the most significant regulations in force in most of the state legal systems. In any case both before national courts and arbitral tribunals, the application of the aforementioned overriding mandatory rules prevails when they are endowed with a significant convention with the contractual relationship with the Principles and with the contractual rules and with any other rule of law adopted on the stock of them or any other title. And in this perspective also transnational public order representative of those principles widely accepted and recognized as essential in the various state systems.

The Principles admit with respect to their normative content the prevalence of uses and practices of international trade established between the contracting parties or widely known and regularly observed in international trade, with the only exceptions of the situations in which their application is unreasonable with respect to the specificity of the case or contrary to the provisions of Principles endowed with a mandatory character.

In this respect, the non-obligatory character and therefore the derogability of Principles with respect to the exercise of private autonomy and the same uses of trade are found with the sole exception of those specific provisions that the Principles define as endowed with mandatory character in function of the their importance with regard to the construction of the operations and values underlying the entire regulatory system of which the Principles constitute the expression.

These are the norms of those principles to which the parties cannot derogate according to the specific imperativity recognized to them and expressly imposed by the same Principles whose character cannot be avoided or evaded by the parties who have voluntarily chosen their application to a specific contractual relationship.

From this point of view, a single function is recognized once again in the exercise of private autonomy, understood in a substantial sense and in its international-private capacity. It is specified that the Principles can be chosen with effects equivalent to those applicable to the contractual situation. When the parties, according to the provisions of the second paragraph of the Preamble, decide to use the international professional technique to regulate their contract directly under the Principles, they are entitled to receive application with all the consequent limits indicated above with regard to the exercise of substantial autonomy with specific regarding the rules equipped with mandatory character. It is confirmed that the Principles are endowed with the character of real and positive legal system according to their suitability to regulate in a tended and self-sufficient manner, as well as inclusive of values that cannot be waived by the will, the arrangements, and contractual relationships of the parties. So much so that in the commentary of art. 1.6, do not hesitate to clarify that also with reference to issues not expressly addressed but to be considered included in the Principles, a solution should be found, whenever possible, within the principles. And in this last regard the need to use the techniques of analogy, extensive interpretation or recourse to the underlying general principles underlying the same Principles is indicated.

Conclusions converging with the foregoing is also reached if the referral expressed by the contracting parties to the Principles is considered as simply aimed at incorporating its content in the context of a contractual framework that includes clauses in conflict with the Principles provisions endowed with mandatory character. In this case, the same effects occur that the (especially French) jurisprudence has specified 
with reference to clauses referring to norms of uniform law which the parties have intentionally extended the material scope of application. In this regard it was stated that if the parties conviennent de soumettre le contrat qu'elles concluent à une convention internationale ne peuvent iscarter celles ou ses prescriptions auxquelles, yes the international convention is applicable to plein droit the ne saurait ètè dèrogè à peine de nullitè/full right the can not be waived under penalty of nullity ${ }^{11}$. If the parties refer to regulations applicable to their contractual relationship, the Principles regulations cannot conventionally derogate from those provisions define as having mandatory character.

Among the Principles provisions endowed with the characters indicated above and therefore suitable to impose themselves to the parties when they have chosen or incorporated them in the contract, we highlight in particular those on good faith and fair dealing (article 1.7), on the possibility of revision of the consideration determined by a contracting party when it is manifestly unreasonable (article 5.1.7, paragraph 29), on the time limits within which the limitation period provided for in article 10.2 may be reduced or extended (article 10.3, paragraph 29), on gross disparity and illegality (article 3.1.4.), as well as on fraud and violence, expressions of protection of incompressible values of the normative system under examination (Liakopoulos, 2018).

The relevance of illegality of contractual clauses and international soft law instruments: The example of principles.

The meaning and scope of normative framework of which the Principles emerges; is a source of soft law of international origin developed by international organizations particularly sensitive to the subject dealt with and attentive to the maximum expansion of private autonomy. And it is precisely in this perspective that in the awareness of ensuring adequate effectiveness to the relative regulatory contents such sources and in particular the Principles themselves, are attentive and sensitive not only to certain mandatory values expressed directly in them but also to those contained in government various titles interested in the regulation of international contractual relations.

With regard to these last three items, as set out in the previous paragraphs, it must be remembered that the new regulation of section 3, chapter 3 , dedicated to illegality, has been taken in the context of Principles. In art. 3.3.1. of the new edition of Principles, the scope and effects of the rules of state origin with a mandatory content that can be applied with different scope of extension, as already indicated with reference to art. 1.4, depending on whether the reference to the Principles is carried out jointly with the provision of an arbitration clause or is intended to operate in the context of disputes resolution submitted to the jurisdiction of a state judge (Schwenzer, 2009, pp. 714ss; Schwenzer, Hachem, Kee, 2012, pp. 838ss; Gllette, 2016).

It should be noted that in all cases where you are dealing with a contract or a part of it that violates a mandatory rule of a state system linked to the contractual relationship by criteria relevant to the international private law (according to the indications pursuant to article 1.4) not only must the relative application be guaranteed but also the consequent effects must be those provided directly within the framework of state origin. Only in the case in which the applicable legal order does not directly foresee such effects on the contractual relationship with specific regard to the rule violated the same Principles provide that the parties can exercise such remedies under the contact as in the circumstances are reasonable, also taking into account the general principles of the legal system to which the violated law belongs.

11. Cassation, 4 February 1992, n . 90-15668 and Court of Appeal of Rouen 8 February 1994 
By virtue of this expression, which is extremely flexible and adaptable to the circumstances of the case, it is therefore possible, depending on the character and effects of the violation, to use various relevant techniques. It will be possible that the part in function of the interest of which the mandatory rule is provided can claim compensation for damages related to the deficiencies of the service performed in violation of such rules or the removal of faults and defects found without being able to invoke the non-collectibility in how much a mandatory rule would have prevented the party in respect of which the relative request to perform the service for which the deficiency is claimed is not applicable, not having the necessary qualifications and/or licenses.

No uncertainty in applying the effects indicated directly by the mandatory rules of state origin when they are expressly provided in them as normally occurs with regard to the rules relating to the prohibition of collusive agreements in violation of public works assignment procedures and anti-corruption provisions or of the rules for the protection of competition or those relating to the protection of assets that are part of the cultural heritage of a state. In all these situations, the illegality of the unlawful conduct is normally accompanied by specific restorers or compensatory remedies as well as by the invalidity of the same contractual relationship in its interests or at least in the part affected by the violation of mandatory rules if it appears to have autonomy and it does not result invasive of its illegality even with respect to the remaining part of the contractual relationship. Through a regulatory soft law instrument, a regulatory framework is guaranteed to allow the parties to regulate their contractual relations by promoting and encouraging market incentives to individual choices freely determined by the contracting parties but also by protecting the publicistic interests of states parties in favor of a regulated market and the maintenance of finished macroeconomic and microeconomic balances deemed essential in the spatial environments in which the effects of contractual relations gravitate, as well as to guarantee the protection of certain categories of subjects.

\section{References}

Aksal, Y. (2011). Implementing international economic law. Through dispute settlement. Martinus Nijhoff Publishers, Leiden/Boston, pp. 158ss.

Andrews, N. (2013). "Civil procedure", in Burrows, A. (ed.), English private law, Oxford University Press, Oxford, 2013, chapter 22.

Ballestros, M.H. (2014). "The regime of party autonomy in the Brussels I Recast: The solutions adopted for agreements on jurisdiction". Journal of Private International Law. 10, pp. 292ss.

Beaumont, P. Danov, M. Trimmings, K. (2017). Cross border litigation in Europe, Hart Publishing, Oxford \& Oregon, Portland, 2017.

Bergè, J.S. Francq, S. Gardens Santiago, M. (2015). Boundaries of European private international law, ed. Bruylant, Bruxelles.

Berger, K.P. (2001). The practice of transnational law, Kluwer Law International, The Hague.

Bergsten, E.E. Kröll, S. (2011). International arbitration and international commercial law, Kluwer Law International, The Hague. 
Boele-Woelki, K. Einhorn, T. Girsberger, D. Symeonides, S. (eds.), (2010). Convergance and divergance in private international law: Liber Amicorum Kurt Siehr, Eleven International Publishing, The Hague, pp. 564ss.

Bonell, M.J. (2006). The Unidroit principles in practice. International case law and bibliography on the Unidroit principles of international commercial contracts, Kluwer, Irvington, New York.

Boyle, A.E. (1999). "Some reflections on the relationship of treaties and soft law". International and Comparative Law Quarterly. 48, pp. 530ss.

Brand, R.A. Fish, T. (2008). "An American perspective on the New Japanese Act on General Rules for Application of Laws". Japanese Yearbook of International Law. pp. 302ss.

Calvo Caravaca, A.L. Carrascosa Gonzàlez, J. (2017). Litigaciòn internacional en la Uniòn Europea II, ed. Comares, Granada, pp. 106ss.

Carruthers, J. (2012). "Party autonomy in the legal regulation of adult relationships: what place for party choice in private international law?". The International \& Comparative Law Quarterly. 61 (4), pp. 881ss.

D'Avout, L. (2010). “Droits fondamentaux et coordination des ordres juridiques en droit privé", in E. Dubout, S. Touzè (a cura di), Les droits fondamentaux: charnières entre ordres juridiques et systèmes juridiques, ed. Pedone, Paris, pp. 184ss.

Dalhuisen, J.H. (2016). Dalhuisen on transnational comparative commercial financial and trade law, Hart Publishing, Oxford \& Oregon, Portland.

Dannemann, G. Vogenauer, S. (2013). The common european sales law in context. Interactions with english and german law, Oxford University Press, Oxford, pp. 16ss.

Delebecque, P. (2016). L'enteprise et la vente internationale de machandises, Larcier, Bruxelles.

Dewez, J. et al., (2011). "The duty to renegotiate an international sales contract under CISG in case of hardship and the use of the Unidroit principles". European Review of Private Law. 19, pp. 102ss.

Di Mateo, L.A. (2014). International sales law: A global challenge, Cambridge University Press, Cambridge.

Felemegas, J. (2007). An international approach to the United Nations Convention on Contracts for the international sale of goods (1980) as uniform sales law. Cambridge University Press, Cambridge.

Ferrari, F. (2011). Contracts for the International Sale of Goods: Applicability and application of the 1980 United Nations Convention, Martinus Nijhoff Publishers, The Hague.

Fletcher, I. Mistelis, L, Cremona M. (eds.), (2001). Foundations and perspectives of international trade law, Sweet \& Maxwell, London. 
Garro, A.M. (1994-1995). "The gap-filling role of the Unidroit principles in international sales law: Some comments on the interplay between the principles an CISG". Tulane Law Review. 69, pp. 1150ss.

Gèlinas, F. (2016). Trade usages and implied terms in the age of arbitration, Oxford University Press, Oxford.

Gillette, C.P. (2016). Advanced introduction to international sales law, Edward Elgar Publishers, Cheltenham.

Honnold, J.P. Flechtner, H.M. (1999). Uniform law for international sales under the 1980 United Nations Convention, Kluwer Law International, The Hague.

Horn, N. Schmitthoff C. (eds.), (1982). The transnational law of international commercial transactions, ed. Kluwer, Deventer.

Horn, N. Schmitthoff, C. Barrigan J. (eds.), (1982). The transnational law of international commercial transactions, Kluwer Law International, Boston.

Jansen, N. Zimermann, R. (2018). Commentaries on European contracts laws, Oxford University Press, Oxford.

Janssen, A. Meyer, O. (2009). CISG methodology, ed. European Law Publishers, Münich, pp. 145ss.

Kjos, J.E. (2013). Applicable law in investor-State arbitration. The interplacy between national and international law, Oxford University Press, Oxford, pp. 123ss.

Komarorv, A.S. (2005-2006). "Internationality, uniformity and observance of good faith as criteria in interpretation of CISG: Some remarks on article 7 (1)". Journal of law and Commerce. 25, pp. 76ss.

Kramer, X.E. (2015). "The interaction between Rome I and mandatory European Union private rules-EPIL and EPL: Communicating vessels?", in Stone, P. Farah, Y. Research Handbook on European Union private international law, Edward Elgar Publishing, Cheltenham, pp. 250ss.

Kroenke, H. (2000). "International uniform commercial law conventions: Advantages, disadvantages, criteria for choice". Uniform Law Review. 13, pp. 14 ss.

Kroll-Ludwigs, K. (2013). Die Rolle der Parteiautonomie in europäischen Kollisionsrecht, ed. Mohr Siebeck, Tübingen, pp. 573ss.

Laird, I.A. Sabqhi, B. Sourgens, F.G. Weiler, T.J. (2015) Investment treaty arbitration and international law, Juris Publishing, New York.

Liakopoulos, D. (2018). "Interactions between European Court of Human Rights and private international law of European Union". Cuadernos de Derecho Transnacional. 10 (1).

Luttrell, S. (2009). Bias challenges in international commercial arbitration. The need for a "real danger" test, Kluwer Law, The Hague, pp. 64ss. 
Mcparland, M. (2015). The Rome I Regulation on the law applicable to contractual obligations, Oxford University Press, Oxford.

Okoli, C.S.A. Arishe, H.O. (2012). "The operation of the escape clauses in the Rome Convention, Rome I Regulation and Rome II Regulation". Journal of Private International Law. 14 (4), pp. 516 ss.

Saumier, G. (2014). "The Hague Principles and the choice of non-State "rules of law" to govern an international commercial contract". Brooklyn Journal of International Law. 40, (1).

Schlechtriem, P. Schwenzer, I. (eds.), (2010). Commentary on the UN Convention on the International Sale of Goods, Oxford University Press, Oxford.

Schlechtriem, P. Witz, C. (2008). Convention de Vienne sur les Contrats de Vente Internationale de Marchandises, ed. LGDJ, Paris.

Schulze, R. (2009). Common frame of reference and existing EC contract law, ed. De Gruyter, Berlin.

Schwenzer, I. (2009). "Force majeure and hardship in international sales contracts". Victoria University of Wellington Law Review. 39 (4), pp. 714ss.

Schwenzer, I. Hachem, P. Kee, C. (2012). Global sales and contract law, Oxford University Press, Oxford, pp. 838ss.

Slater, S.D. (1998). "Overcome by hardship: the inapplicability of the Unidroit principles hardship provisions to CISG". Florida Journal of International Law. 12, pp. 232ss.

Smith, Q. (2011). "Reviewing the history and application of article 7 of the Convention on the International Sale of Goods (CISG)". Transnational Dispute Management, 8, pp. 2ss.

Symeonides, S. (2006). "Contracts subject to non-State norms". American Journal of Comparative Law. pp. 210ss.

Teubner G. (ed.), (1997). Global law without a State, Darthmouth Publishing, Dartmouth

Van Houtte, V. (2002). The law of international trade, Sweet \& Maxwell, London.

Waincymer, J. (2012). Procedure and evidence in international arbitration, Kluwer Law International, Alphen aan den Rijn, pp. 5ss.

Wais, H. (2017). “Einseitige Gerichtsstandverinbarungen und die Schranken der Parteiautonomie". Rabels Zeitschrift für ausländisches und internationales Privatrecht. 81

Wautelet, P. Kruger, T. Coppens, G. (2012). The protection of arbitration. Essays in honour of Hans Van Houtte, Hart Publishing, Oxford \& Oregon, Portland. 